\title{
Impact of MS concentration and light qualities on alpine red ginger elongation and rooting in vitro
}

\author{
Marcos Vinícius Marques Pinheiro ${ }^{1 *}$, Alana Paula Chiavagatti Schmidt² ${ }^{2}$ Guilherme Masarro-Araujo ${ }^{2}$, \\ Evandro Holz ${ }^{2}$, Wagner Campos Otoni ${ }^{3}$, Denise Schmidt ${ }^{2}$
}

ABSTRACT

\begin{abstract}
Some factors in in vitro cultivation, such as formulation of the culture medium and the quality of the light source, may vary the response of the plants in those conditions, favoring the photosynthetic metabolism obtaining more rustified plants capable of benefiting from the conditions of ex vitro cultivation. Thus, the objective was to evaluate in vitro elongation/rooting of Alpinia purpurata cv. Red Ginger under different light-emitting diodes (LEDs) and saline concentration of the MS medium. For this, previously established in vitro plants were maintained for 55 days in $550 \mathrm{~mL}$ glass flasks containing Carolina ${ }^{\circledR}$ substrate and MS culture medium with different salt concentrations, under LEDs qualities. The following parameters were evaluated: number of green and senescent leaves, shoot length, length of the largest root, fresh and dry mass of leaves, stem and root, root volume, photosynthetic pigments [chlorophyll $a$, chlorophyll $b$, total chlorophylls $(a+b)$ and carotenoids $\left(\mu \mathrm{g} \mathrm{cm}^{-2}\right)$ ], stomatal density and acclimatization percentage (after 33 days of ex vitro cultivation). After 55 days, plants grown under red LEDs and full-strength MS culture medium is indicated and promote efficient shoot length and photosynthetic pigment content, respectively. These conditions provided plants better adapted for ex vitro acclimatization.
\end{abstract}

Index terms: Alpinia purpurata; light-emitting diode (LEDs); culture medium.

\section{INTRODUCTION}

The Zingiberaceae family comprises perennial monocotyledonous plants distributed in tropical regions around the world (Raju et al., 2019). The species Alpinia purpurata is marked by the beauty of the inflorescences, with lush green leaves and large and attractive bracts, which justifies the commercialization of plants and their flowers besides the use in landscaping (Chan; Wong, 2015; Sanches et al., 2016). These plants have important medicinal properties present in essential oils, popularly used in the treatment of various diseases, such as hypertension, inflammatory processes, and other therapeutic potentials, as well as in cooking such as spices and condiments in many regions of Asia (Victorio, 2011 ; Ghosh; Rangan, 2013; Chan; Wong, 2015).

The largest production of plants of this species occurs by vegetative propagation via rhizomes; however, the main disadvantage is the spread of diseases that can occur in successive plantings. Thus, in vitro cultivation is an important technique to produce plants from tissues, organs or cells grown in culture medium with necessary nutrients, energy and water
(Phillips; Garda, 2019) and that promotes the massive propagation of several plants with physiological and phytosanitary quality (Araruna et al., 2017). MS medium (Murashige; Skoog, 1962), initially formulated for the cultivation of Nicotiana sp., has been used for various herbaceous species and ornamental plants, including alpines. However, the response of plants may vary depending on the culture medium used and the formulation of salts, as well as phytohormones, since the concentrations of these elements and other osmotically active compounds may culminate in the activation or inactivation of the metabolic pathways that proceed in vitro plant development (Araruna et al., 2017).

The quantity and quality of light influence the absorption of nutrients by the roots, directly affecting plant growth and development (Sakuraba; Yanagisawa, 2018; Ferreira et al., 2016). Light-emitting diodes (LEDs) are low-cost light sources used in plant production and have specific wavelengths and intensities, being found in blue (450-470 $\mathrm{nm}$ ) and red LEDs (650-665 nm), capable of triggering photoreceptors to induce morphological and physiologically responses in plants such as rooting

*Corresponding author: macvini@gmail.com 
or branch elongation (Yeh, 2009; Agarwal; Gupta, 2016; Huché-Thélier et al., 2016; Senol; Kilic; Tasdelen, 2016; Batista et al., 2018).

In conventional in vitro cultivation, there may be restriction of the photosynthetically photon flux, reduced gas exchange and decreased rates of transpiration and photosynthesis, reducing the production of photoassimilates, which may lead to reduced survival rate during culture acclimatization (Kozai, 2010; Xiao; Niu; Kozai, 2011). Some factors in in vitro cultivation, such as changing the culture medium, imposing gas exchange, reducing relative humidity and the quality and intensity of light can benefit the photosynthetic metabolism of plants, obtaining more rustified plants and better able to adapt to ex vitro conditions (Couto et al., 2014; Xiao; Niu; Kozai, 2011; Rodrigues et al., 2011).

In this way, the present study aimed to evaluate the in vitro elongation and rooting of Alpinia purpurata cv. Red Ginger under different light qualities LEDs and MS salt concentrations and the impact on the vitroplants acclimatization.

\section{MATERIAL AND METHODS}

\section{Plant material and growing conditions}

Alpinia purpurata cv. Red Ginger were previously successively subcultured (six times) until there are enough adventitious shoots necessary, in MS culture medium supplemented with $1.5 \mathrm{mg} \mathrm{L}^{-1}$ 6-benzyladenine (6-BA), $0.1 \mathrm{mg} \mathrm{L}^{-1} \alpha$-naphthalenoacetic acid (ANA), $100 \mathrm{mg} \mathrm{L}^{-1}$ myo-inositol, $30 \mathrm{~g} \mathrm{~L}^{-1}$ sucrose, solidified with $6 \mathrm{~g} \mathrm{~L}^{-1}$ agar (AgarGel ${ }^{\circ}$, João Pessoa, PB, Brazil), and $\mathrm{pH}$ adjusted to 5.8, previously autoclaved at $121{ }^{\circ} \mathrm{C}$ and $1.5 \mathrm{~atm}$ for 15 minutes. The plants were maintained under controlled growth room conditions, with a temperature of $25 \pm$ $2{ }^{\circ} \mathrm{C}, 16$ hours light photoperiod, under $72 \mu \mathrm{mol} \mathrm{m} \mathrm{m}^{-2} \mathrm{~s}^{-1}$ irradiance provided by white LEDs lamps.

To conduct the experiment, two adventitious shoots (approximately $5 \mathrm{~cm}$ with three to five expanded leaves) were used per $550 \mathrm{~mL}$ volume flask, sealed with a metal lid with two $8 \mathrm{~mm}$ holes, covered by porous membranes, made according to the methodology of Saldanha et al. (2012). In each flasks, $40 \mathrm{~mL}$ of culture medium was used $[100 \%$ salt MS (MS) or $50 \%$ salt MS
(MS1/2)], added $0.1 \mathrm{mg} \mathrm{L}^{-1} \mathrm{ANA}, 100 \mathrm{mg} \mathrm{L}^{-1}$ myo-inositol, $30 \mathrm{~g} \mathrm{~L}^{-1}$ sucrose, with $20 \mathrm{~g}$ of Carolina substrate per flask. The $\mathrm{pH}$ was adjusted to $5.8 \pm 0.1$ prior to autoclaving. After inoculation, the vegetative materials were kept for 55 days in a growth room with 16 hours photoperiod, $72 \mu \mathrm{mol} \mathrm{m}^{-2} \mathrm{~s}^{-1}$ irradiance, from two TECNAL TEC LAMP tubular lamps for each color [white LEDs; blue LEDs; red LEDs or red/blue LEDs (at 60 and $40 \%$, respectively)], and temperature of $25 \pm 2{ }^{\circ} \mathrm{C}$.

\section{Experimental design and analyzed variables}

The experiment was conducted in a completely randomized design, in a $4 \times 2$ bifactorial scheme, with four light qualities (white LEDs, blue LEDs, red LEDs and red/blue LEDs) and two MS salts concentrations (full strength (100\%) - MS; and half strength - MS1/2), totaling eight treatments, varying the number of repetitions for the variables analyzed and the experimental unit. All variables were evaluated at 55 days of in vitro culture, and acclimatization percentage variable after 33 days of ex vitro cultivation.

\section{Growth measurements}

For the variables number of shoots, number of green leaves, number of senescent leaves, shoot length $(\mathrm{cm})$, largest root length $(\mathrm{cm})$, fresh and dry leaf mass $(\mathrm{g})$, fresh and dry stem mass $(\mathrm{g})$, fresh and dry root mass $(\mathrm{g})$, root volume $(\mathrm{mL})$, five replicates were used, and the experimental unit was composed of two plants per flask.

\section{Photosynthetic pigments}

To determine the photosynthetic pigments, chlorophylls $a$ (Chla) and $b$ (Chlb), total chlorophylls ( $a+b$; ChIT) and carotenoids, five discs, $5 \mathrm{~mm}$ in diameter each, were obtained from second leaf green of plants (from apex to base) and incubated in glass tubes containing 5 $\mathrm{mL}$ of dimethyl sulfoxide (DMSO) saturated with calcium carbonate $\left(\mathrm{CaCO}_{3}\right)$, kept in glass tubes and in the dark, according to the adjusted methodology of Santos et al. (2008), totaling four repetitions for each treatment. After 48 hours in the dark, absorbance was determined on a SPECORD 50 / PLUS ${ }^{\circledR}$ spectrophotometer (Analytikjena, Germany) using a $10 \mathrm{~mm}$ quartz cuvette. Wellburn (1994) methodology was followed to establish wavelengths and equations to calculate the concentrations of chlorophylls 
$[a, b$, totals $(a+b)]$ and carotenoids (CAR) and the unit of these variables being in $\mu \mathrm{g} \mathrm{cm}^{-2}$.

For the photosynthetic pigments variables [chlorophyll $a$, chlorophyll $b$, total chlorophylls $(a+b)$ and carotenoids $\left(\mu \mathrm{g} \mathrm{cm}^{-2}\right)$ ] four replications were used and the experimental unit consisted of a glass tube).

\section{Stomatal density}

The stomatal density (stomata $\mathrm{mm}^{-2}$ ) was performed using the epidermis printing technique from the methodology described by Weyers and Johansen (1985), with a drop of cyanoacrylate ester under the glass slide. The abaxial or adaxial face of the first fullyexpanded and green leaf from the apex to the base of the plant was pressed for approximately 30 seconds, leaving the impression of the epidermis on the blade. From the prepared slides, images were captured with the aid of a LEICA ${ }^{\circ}$ (DM 1000 - Leica) optical microscope coupled to a camera (DFC 295 - Leica), using a 20x magnification (area of $596 \times 447 \mu \mathrm{m})$. The determination of stomatal density was performed using the Anati Quant 2 software, from the stomatal cell count.

Because it is an amphistomatic species with greater amounts of stomata on the abaxial face, stomatal density was performed on both sides, adaxial and abaxial faces of the leaf, four repetitions and the experimental unit composed by a blade with paradermic impression of both sides of the leaf.

\section{Acclimatization}

After 33 days of ex vitro cultivation, the acclimatization percentage was evaluated, using three replications, in which each experimental unit was composed of two plants. Plants with 55 days of in vitro cultivation in MS salts concentrations and light qualities, as described above, were transferred to plastic bottles containing Carolina ${ }^{\circ}$ substrate in greenhouse for more 33 days, with daily average temperature of 20 to $30^{\circ} \mathrm{C}$, kept in sombrite $60 \%$ and regularly irrigated.

\section{Statistical analysis}

The variables were subjected to analysis of variance and the means were compared by the Scott-Knott $5 \%$ probability test using the SISVAR software (Ferreira, 2011).

\section{RESULTS AND DISCUSSION}

By the analysis of variance $F$ test at $5 \%$ of significance, there was no significant difference for the light quality factor for the variables shoot length $(\mathrm{cm})$, number of shoots, fresh leaf mass (g) and chlorophyll $b$ (chlb, $\mu \mathrm{g} \mathrm{cm}^{-2}$ ). Considering chlorophyll $a$ (Chla, $\mu \mathrm{g} \mathrm{cm}^{-2}$ ), total chlorophyll (ChIT, $\mu \mathrm{g} \mathrm{cm}^{-2}$ ), carotenoids (CAR, $\mu \mathrm{g}$ $\mathrm{cm}^{-2}$ ) and abaxial stomatal density there was significant difference only for the MS concentrations factor, and adaxial stomatal density there was no significant difference for any factor. There was a significant difference for the interaction between the factors for acclimatization percentage variable $(p<0.05)$. For the other variables analyzed (number of green leaves, number of senescent leaves, length of the largest root, root volume, leaf dry mass, root fresh and dry mass and stem fresh and dry mass) there were no significant differences.

Plants grown under white LEDs and red/blue LEDs induced higher number of shoots (0.85 and 0.67, respectively) than the other light qualities (Figure $1 \mathrm{~A}$ ). Similar results were observed in Saccharum officinarum, which in white LEDs promoted a higher number of shoots (Ferreira et al., 2016) and under red/blue LEDs in Corymbia (Souza et al., 2019).

The red LEDs promoted higher shoot length (7.91 $\mathrm{cm})$, according to Figure 1B. Similar results were observed in gerbera plantlets besides stimulated adventitious root formation (Pawłowska et al. 2018). Light quality, among other factors of occurrence in in vitro condition, can influence the shoots number, providing different effects on plant growth and morphogenesis (Li; Tang; Xu, 2013).

Blue and red/blue LEDs provided higher fresh leaf mass accumulation ( 0.17 and $0.14 \mathrm{~g}$, respectively) (Figure 1C), probably the blue light increased the leaf area and the fresh leaf mass accumulation of alpinia plants. This higher fresh leaf mass is related to the higher photosynthetic activities induced by those light qualities. Red/blue LEDs provided higher fresh mass accumulation in Doritaenopsis (Shin et al., 2008); which is correlated with higher photosynthetic efficiency due to wavelength peaks close to chlorophyll absorption and carbohydrate accumulation increased by red light spectrum (Rocha et al., 2013). 

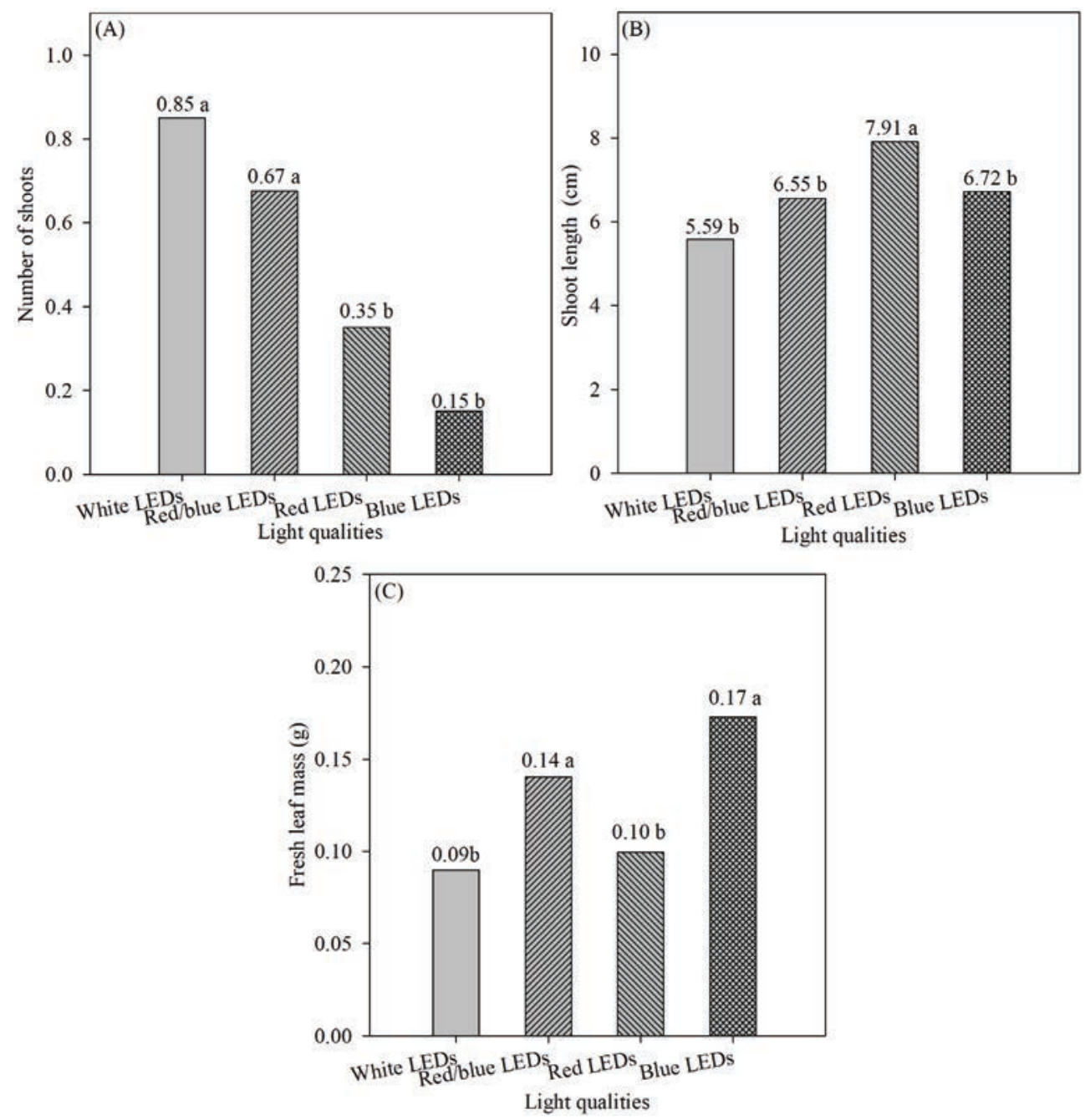

Figure 1 - Number of shoots (A), shoot length (cm) (B) and fresh leaf mass (g) (C) of Alpinia purpurata in different light qualities. *Equal letters do not differ from each other by the Scott-Knott test at $5 \%$ probability.

Exposure to red LEDs increased stem elongation and to blue LEDs reduced plant height (Figure 2E - H). Daud, Faizal and Geelen (2013) report the red LEDs benefits to shoot growth in Jatropha curcas. This fact can be attributed to the shortening of internodes and reduction of cell lengthening caused by blue light (Huché-Thélier et al., 2016; Metallo et al., 2018). As a result, alpine plants submitted to this light spectrum presented shoot length increase.

The Chla of the plants submitted to the MS medium was superior $\left(20.09 \mu \mathrm{g} \mathrm{cm}^{-2}\right)$ when compared to MS $1 / 2$ (Figure $3 \mathrm{~A})$, being also superior for carotenoids $(4.85 \mu \mathrm{g}$ $\left.\mathrm{cm}^{-2}\right)$ (Figure 3B) and for total chlorophyll $\left(22.89 \mu \mathrm{g} \mathrm{cm}^{-2}\right)$ (Figure $3 \mathrm{C}$ ). There is a relationship between chlorophyll contents and nutrients nitrogen and magnesium are known to be constituents of the chlorophyll molecule. Considering that in the MS1/2 culture medium these nutrients are half their concentrations, this fact explaining the relationship of nutrients to the amount of chlorophylls. When properly supplemented with nutrient doses such as nitrogen, magnesium, potassium and sulfur, present higher levels of photosynthetic pigments, chlorophyll and carotenoids (Freire et al., 2013). In our work, the complete MS medium provided higher accumulation of $\mathrm{Chla}$, Chl $T$ and CAR due to the greater availability of nutrients that are primordial in the constitution of photosynthetic pigments. However, this response is species dependent, 


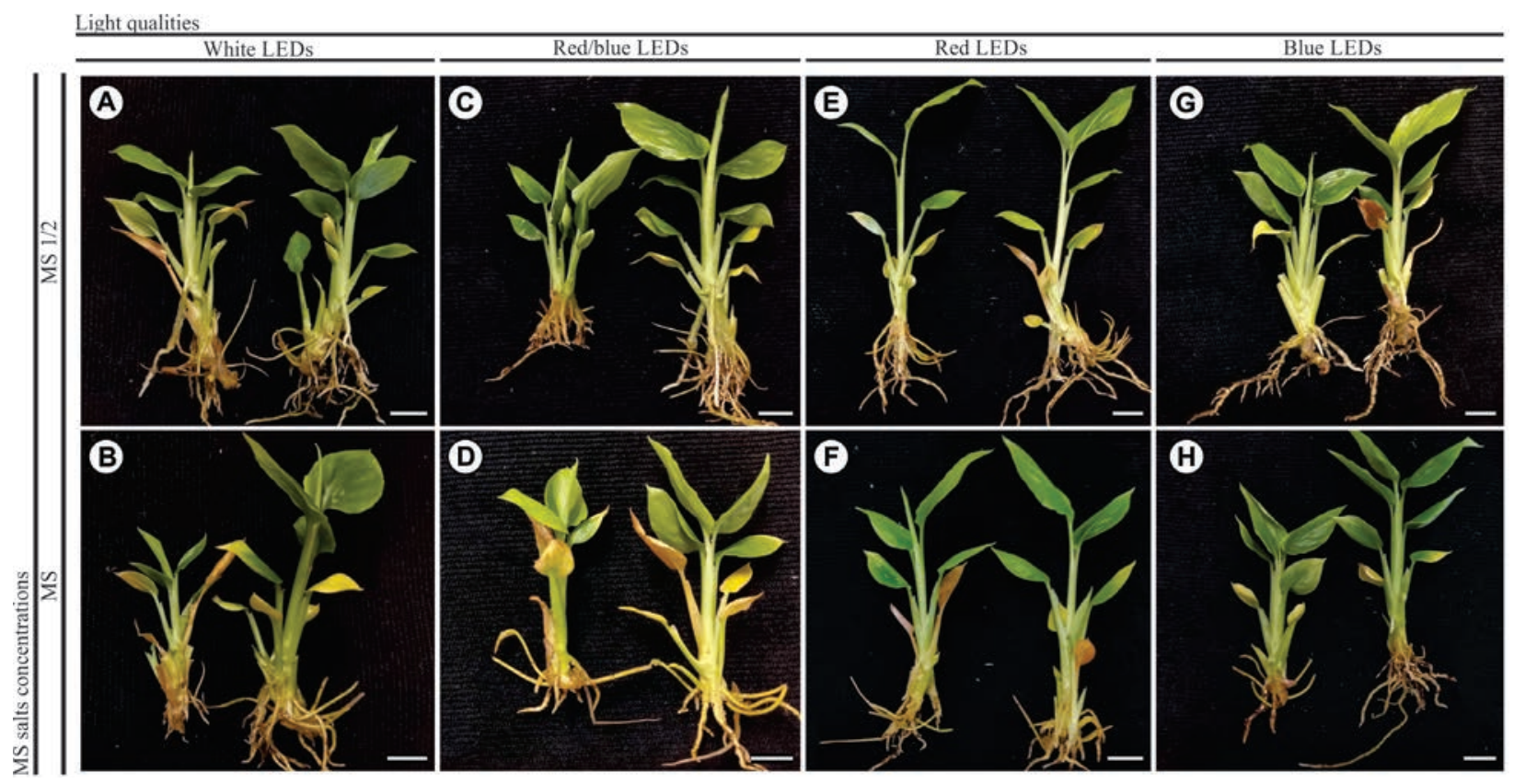

Figure 2 - Alpinia purpurata at 55 days in vitro maintained at light qualities and MS salts concentrations [white LEDs $(W L)+M S 1 / 2(A)$, white LEDs + MS (B), red/blue LEDs + MS 1/2 (C), red/blue LEDs + MS (D), red LEDs + MS $1 / 2$ (E) and Red LEDs + MS (F) LEDs, Blue LEDs + MS 1/2 (G) Blue LEDs + MS (H)]. Bars: $1 \mathrm{~cm}$.

for example, the use of half of macro and micronutrient concentrations benefited the elongation and rooting in vitro of banana cv. Pacovan (Musa sp.) (Pinheiro; Carvalho; Martins, 2018).

Plants kept under white LEDs produced a higher concentration of $\mathrm{Chlb}\left(3.13 \mu \mathrm{g} \mathrm{cm}^{-2}\right)$ when compared to other LEDs (Figure 3D). Similar results were obtained by Ferreira et al. (2016) with Saccharum officinarum. Thus, white LEDs provided greater accumulation of Chlb, since the composition of the pigments that are part of the photosynthesis process is influenced by the light quality, which also has the effect of delaying chlorophyll degradation (Darko et al., 2014; Streit et al., 2005). Thus, white LEDs favored the biosynthesis/conservation of $\mathrm{Chl} b$, and for the other LEDs provided the degradation of this pigment.

For the stomatal density in the leaf abaxial epidermis, the significant difference was observed for the MS salt concentrations, in this case there was higher stomatal density in MS medium (78.36 stomata $\mathrm{mm}^{-2}$ ) when compared to MS $1 / 2$ (Figure $3 \mathrm{E}$ ). The reduction of stomatal density in the presence of smaller salt concentrations in the culture medium may be a way of adapting to nutrient restriction conditions.

For acclimatization percentage, although presenting interaction between light qualities and MS salt concentrations, the significant difference was only observed for plants grown under white LEDs, in the different MS salt concentrations. MS1/2 was the one that provided the highest percentage of plant acclimatization (90\%), after remaining 33 days in a protected environment (Figure 4 and 5). For the others light qualities, there were no difference between MS and MS1/2. The reduction of salts from MS medium to MS1/2 in a study with Schomburgkia gloriosa provided higher average growth variables, being more efficient and less expensive (Dezan et al., 2012), due to the reduction in half of the ingredients that are part of the MS medium. This may explain the greater percentage in the acclimatization of the present study, in which, even without significant difference (except for white LEDs) between MS and MS1/2, treatments with MS1/2 had a higher survival percentage (Figure 4). The success of tissue culture is influenced by the nature of culture medium used and the ability of plants to adapt to 

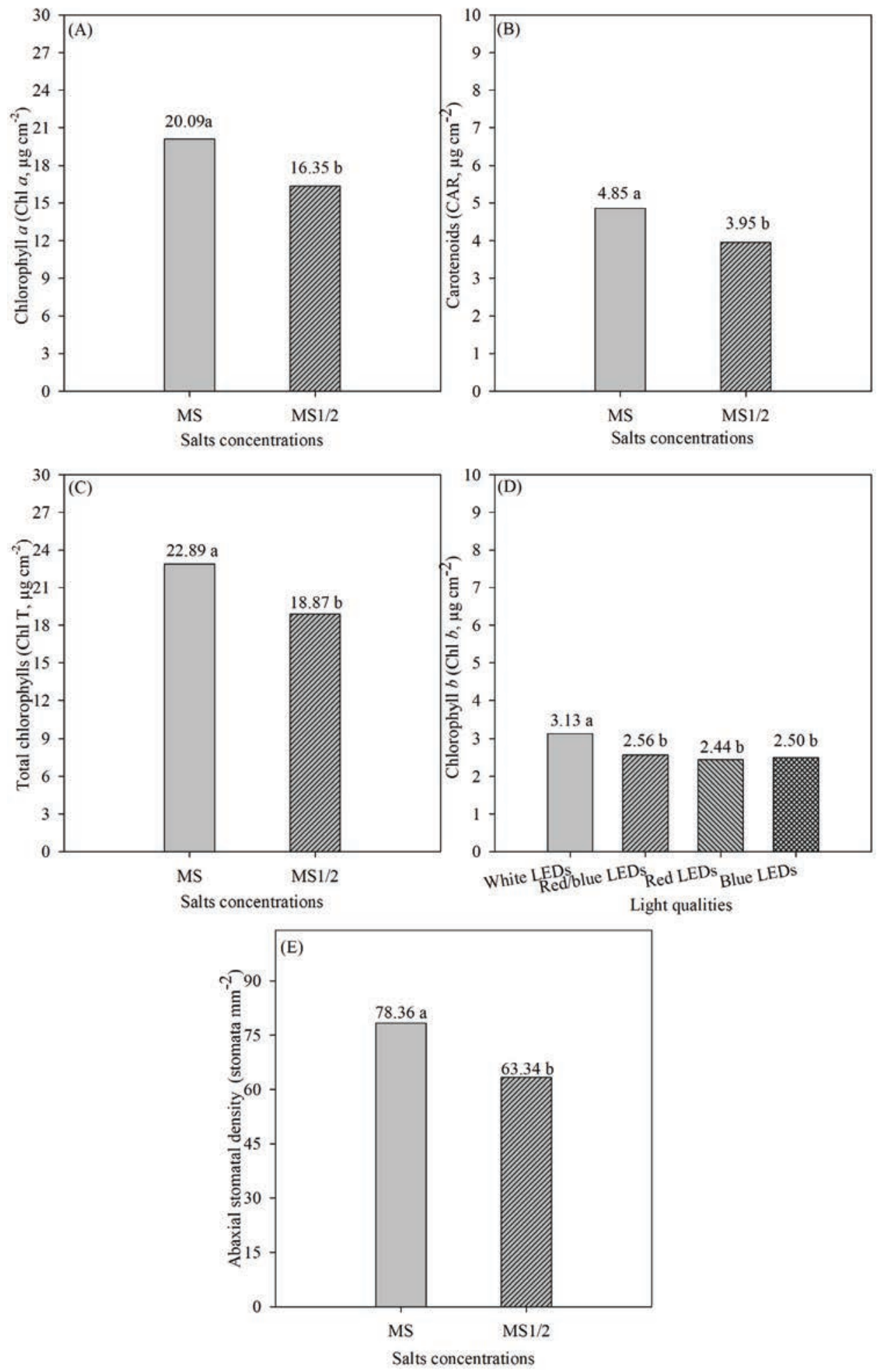

Figure 3 - Chlorophyll $a$ (Chla, $\mu \mathrm{g} \mathrm{cm}^{-2}$ ) (A), carotenoids (CAR, $\mu \mathrm{g} \mathrm{cm}^{-2}$ ) (B), Total chlorophyll (ChlT, $\left.\mu \mathrm{g} \mathrm{cm}^{-2}\right)(\mathrm{C})$, as a function of MS concentrations of the culture medium; chlorophyll $b\left(\mathrm{Chl} b, \mu \mathrm{g} \mathrm{cm}^{-2}\right)(D)$ as a function of light qualities; and abaxial stomatal density (stomata $\mathrm{mm}^{-2}$ ) (E) of Alpinia purpurata. *Equal letters do not differ from each other by the Scott-Knott test at 5\% probability. 


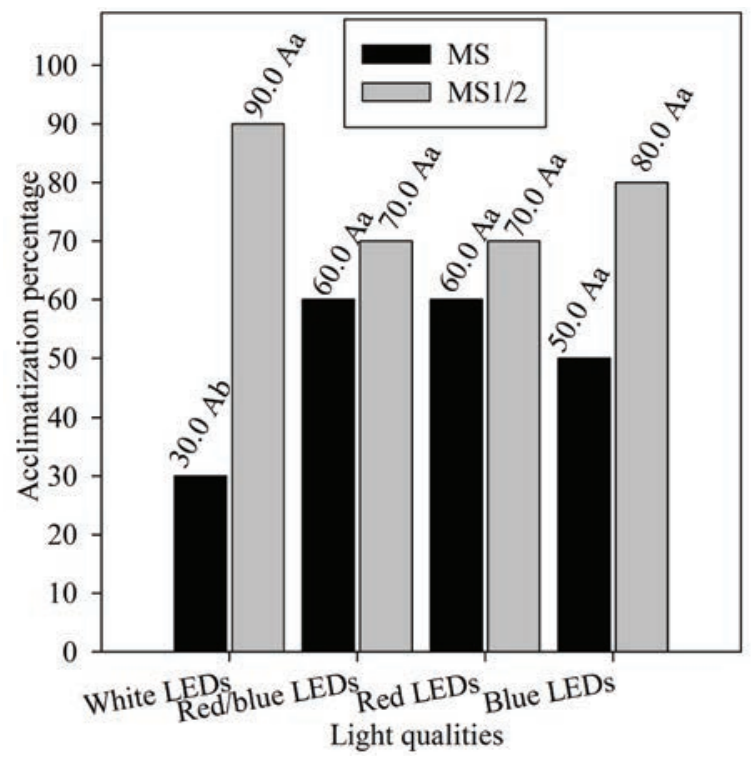

Figure 4-Acclimatization percentage (\%) of Alpinia purpurata submitted to different MS salts concentrations (MS and MS $1 / 2$ ) and different light qualities. * Lower case letters in the same culture medium do not differ in light qualities; and capital letters in the same light quality do not differ the MS salts concentrations by the Scott-Knott test at $5 \%$ probability. natural environmental condition after the completion of in vitro production that is acclimatization ex vitro (Zahara; Datta; Boonkorkaew, 2016).

We observed that the increase of shoots length favors rooting and acclimatization, ie, when we observe the growth variables under the white LEDs, the number of shoots presented higher average.

In general, the high percentage of acclimatization observed for this species may be related to the gas exchange provided during the in vitro cultivation. Plant acclimatization occurs from morphophysiological modifications that can be observed in plants exposed to atmospheric-like $\mathrm{CO}_{2}$ concentrations still in vitro cultivation (Batista et al., 2017); This cultivation characteristic can be provided by the presence of porous membranes to gases, which allows better exposure to $\mathrm{CO}_{2}$ (Batista et al., 2017); providing in turn, higher shoot quality and survival, lower chlorosis, and senescence during ex vitro acclimatization (Nguyen; Xiao; Kozai, 2016; Pérez-Jiménez et al., 2015; Rodrigues et al., 2011; Walter; Rosa; Streeck, 2015).

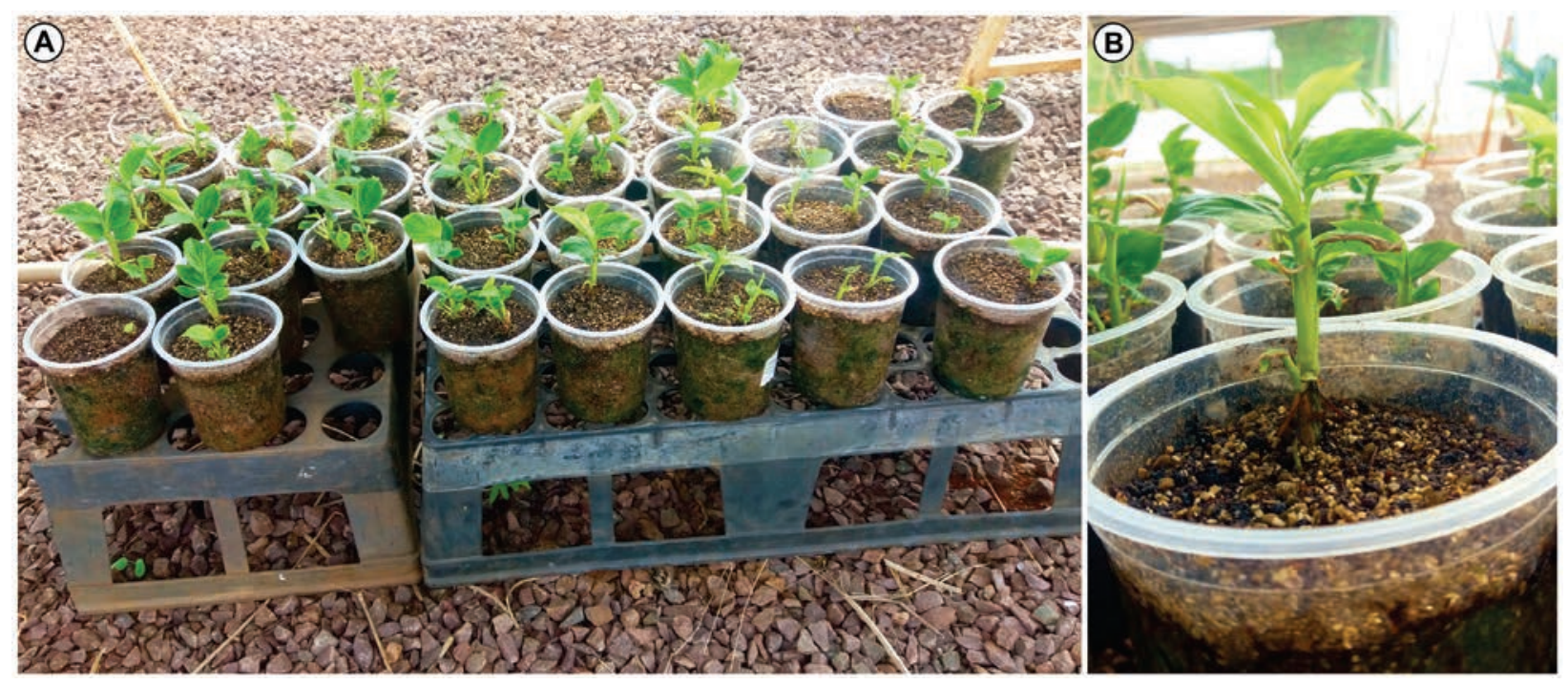

Figure 5 -Alpinia purpurata plants from different MS salts concentrations and light qualities, maintained for 33 days under greenhouse (A and B). 


\section{CONCLUSIONS}

In vitro cultivation of Alpinia purpurata with red LEDs and full-strength MS culture medium is indicated, as they promote efficient shoot length and photosynthetic pigment content, respectively. These conditions provided plants better morphophysiologically adapted for ex vitro acclimatization.

\section{ACKNOWLEDGEMENTS}

The authors thank the Coordination for the Improvement of Higher Education Personnel (Coordenação de Aperfeiçoamento de Pessoal de Nível Superior-CAPES) (Brasília, DF, Brazil) for a postdoctoral fellowship to the first author.

\section{REFERENCES}

AGARWAL, A.; GUPTA, S. D. Impact of light-emitting diodes (LEDs) and its potential on plant growth and development in controlled-environment plant production system. Current Biotechnology, 5(1):28-43, 2016.

ARARUNA, E. C. et al. Salt concentrations in culture media for the development of Dipteryx alata in vitro. Pesquisa Agropecuária Brasileira, 52(12):1295-1300, 2017.

BATISTA, D. S. et al. Light quality in plant tissue culture: Does it matter? In Vitro Cellular \& Developmental Biology - Plant, 54:195-215, 2018.

BATISTA, D. S. et al. Elevated $\mathrm{CO}_{2}$ improves growth, modifes anatomy, and modulates essential oil qualitative production and gene expression in Lippia alba (Verbenaceae). Plant Cell, Tissue and Organ Culture, 128:357-368, 2017.

CHAN, E. W. C.; WONG, S. K. Phytochemistry and pharmacology of ornamental gingers, Hedychium coronarium and Alpinia purpurata: A review. Journal of Integrative Medicine, 13(6):368-379, 2015.

COUTO, T. R. et al. Eficiência fotossintética e crescimento de genótipos de abacaxizeiro cultivados in vitro em diferentes qualidades de luz, tipos de frasco de cultivo e concentrações de sacarose. Revista Brasileira de Fruticultura, 36(2):459466, 2014.

DAUD, N.; FAIZAL, A.; GEELEN, D. Adventitious rooting of Jatropha curcas $L$. is stimulated by phloroglucinol and by red LED light. In Vitro Cellular \& Developmental Biology-Plant, 49:183-190, 2013.
DARKO, E. Photosynthesis under artificial light: The shift in primary and secondary metabolism. Philosophical Transactions of The Royal Society B, 369(1640):20130243, 2014.

DEZAN, L. F. In vitro growth of Schomburgkia gloriosa Lindl. using simplified culture media. Idesia, 30:53-58, 2012.

FERREIRA, D. F. Sisvar: A computer statistical analysis system. Ciência e Agrotecnologia, 35(6):1039-1042, 2011.

FERREIRA, L. T. et al. Fonte de luz e concentração de sacarose no cultivo in vitro da cana-de-açúcar (RB 867515). Plant Cell Culture \& Micropropagation, 12(2):46-52, 2016.

FREIRE, J. L. O. et al. Teores de clorofila e composição mineral foliar do maracujazeiro irrigado com águas salinas e biofertilizante. Revista de Ciências Agrárias, 36(1):57-70, 2013.

GHOSH, S.; RANGAN, L. Alpinia: The gold mine of future therapeutics. 3 Biotech, 3(3):173-185, 2013.

HUCHÉ-THÉLIER, L. et al. Light signaling and plant responses to blue and UV radiations - Perspectives for applications in horticulture. Environmental and Experimental Botany, 121:22-38, 2016.

KOZAI, T. Photoautotrophic micropropagation: Environmental control for promoting photosynthesis. Propagation of Ornamental Plants, 10(4):188-204, 2010.

LI, H.; TANG, C.; XU, Z. The effects of different light qualities on rapeseed (Brassica napus L.) plantlet growth and morphogenesis in vitro. Scientia Horticulturae, 150:117124, 2013.

METALLO, R. M. et al. Influence of blue/red vs. white LED light treatments on biomass, shoot morphology, and quality parameters of hydroponically grown kale. Scientia Horticulturae, 235:189-197, 2018.

MURASHIGE, T.; SKOOG, F. A revised medium for rapid growth and bio assays with tobacco tissue cultures. Physiologia Plantarum, 15:473-497, 1962.

NGUYEN, Q. T.; XIAO, Y.; KOZAI, T. Photoautotrophic micropropagation. In: KOZAI, T.; NIU, G.; TAKAGAKI, M. (Ed.). Plant Factory. Burlington: Academic Press, 2016. p.271-283.

PAWŁOWSKA, B. et al. Impact of LED light sources on morphogenesis and levels of photosynthetic pigments in Gerbera jamesonii grown in vitro. Horticulture, Environment, and Biotechnology, 59:115-123, 2018. 
PÉREZ-JIMÉNEZ, M. et al. A regime of high $\mathrm{CO}_{2}$ concentration improves the acclimatization process and increases plant quality and survival. Plant Cell, Tissue and Organ Culture, 121:547-557, 2015.

PHILLIPS, G. C.; GARDA, M. Plant tissue culture media and practices: An overview. In Vitro Cellular \& Developmental Biology - Plant, 55(3):242-257, 2019.

PINHEIRO, M. V. M.; CARVALHO, A. C. P. P. D.; MARTINS, F. B. Modificações no meio de cultura, fotoperíodo e tempo de cultivo afetam o alongamento e enraizamento in vitro de bananeira cv. pacovan. Nativa, 6:27-32, 2018.

RAJU, R. et al. Diarylheptanoids with anti-inflammatory activity from the rhizomes of Pleuranthodium racemigerum (Zingiberaceae). Phytochemistry Letters, 30:10-13, 2019.

ROCHA, P. S. G. da et al. Diodos emissores de luz (LEDs) na micropropagação de amoreira-preta cv. Tupy. Horticultura Argentina. 32(79):14-19, 2013.

RODRIGUES, M. et al. Effects of flask sealing and growth regulators on in vitro propagation of neem (Azadirachta indica A. Juss.). In Vitro Cellular \& Developmental BiologyPlant, 48:67-72, 2011.

SAKURABA, Y.; YANAGISAWA, S. Light signalling-induced regulation of nutrient acquisition and utilization in plants. Seminars in Cell and Developmental Biology, 83:123-132, 2018.

SALDANHA, C. W. et al. A low-cost alternative membrane system that promotes growth in nodal cultures of Brazilian ginseng [Pfaffia glomerata (Spreng.) Pedersen]. Plant Cell, Tissue and Organ Culture, 110:413-422, 2012.

SANCHES, A. G. et al. Stem cutting size and biofilm in longevity of ornamental ginger. Nativa, 4(5):337-341, 2016.

SANTOS, R. P. et al. Protocolo para extração de pigmentos foliares em porta-enxertos de videira micropropagados. Revista Ceres, 55(4):356-364, 2008.
SENOL, R.; KILIC, S.; TASDELEN, K. Pulse timing control for LED plant growth unit and effects on carnation. Computers and Electronics in Agriculture, 123:125-134, 2016.

SHIN, K. S. et al. The effect of light quality on the growth and development of in vitro cultured Doritaenopsis plants. Acta Physiologiae Plantarum, 30(3):339-343, 2008.

SOUZA, D. M. S. C. et al. Light quality in the in vitro introduction of Corymbia hybrid clones. Revista Árvore, 42(6):1-9, 2019.

STREIT, N. M. et al. As clorofilas. Ciência Rural, 35(3):748-755, 2005.

VICTORIO, C. P. Therapeutic value of the genus Alpinia, Zingiberaceae. Revista Brasileira de Farmacognosia, 21(1):194-201, 2011.

WALTER, L. C.; ROSA, H. T.; STREECK, N. A. Mecanismos de aclimatação das plantas à elevada concentração de $\mathrm{CO}_{2}$. Ciência Rural, 45(9):1564-1571, 2015.

WELLBURN, A. R. The spectral determination of chlorophylls a and $b$, as well as total carotenoids, using various solvents with spectrophotometers of different resolution. Journal of Plant Physiology, 144:307-313, 1994.

WEYERS, J. D. B.; JOHANSEN, L. G. Accurate estimation of stomatal aperture from silicone-rubber impressions. New Phytologist, 101(1):109-115, 1985.

XIAO, Y.; NIU, G.; KOZAI, T. Development and application of photoautotrophic micropropagation plant system. Plant Cell, Tissue and Organ Culture, 105:149-158, 2011.

YEH, N.; CHUNG, J.-P. High-brightness LEDs - Energy efficient lighting sources and their potential in indoor plant cultivation. Renewable and Sustainable Energy Reviews, 13(8):2175-2180, 2009

ZAHARA, M.; DATTA, A.; BOONKORKAEW, P. Effects of sucrose, carrot juice and culture media on growth and net $\mathrm{CO}_{2}$ exchange rate in Phalaenopsis hybrid "Pink.". Scientia Horticulturae, 205:17-24, 2016. 